\section{Semarang State University Undergraduate LAWE SOCIETY REVIEW}

VOLUME 1 ISSUE 2, JULY 2021
ISSN (Print): 2807-8225 ISSN (Online): 2807-8683

\section{History of Article}

Submitted: December 2020

Revised: March 2021

Accepted: May 2021

How to cite:

Lestari, L. W. (2021). Book Review Letter of the Law, Alan Edward Nourse, Publisher Library of Alexandria, 2000, ISBN 1492373567. Semarang State University Undergraduate Law and Society Review, 1(2), 203-210. https://doi.org/10.15294/lsr.v1i2.50615

(C) 2021 Authors. This work is licensed under a AttributionNonCommercial-ShareAlike 4.0 International (CC BY-NC-SA 4.0). All writings published in this journal are personal views of the authors and do not represent the views of this journal and the author's affiliated institutions.

\title{
Book Review Letter of the Law, Alan Edward Nourse, Publisher Library of Alexandria, 2000, ISBN 1492373567
}

\section{Liza Winda LESTARI@}

Faculty of Law, Universitas Negeri Semarang

Jl. Taman Siswa, Sekaran, Gunungpati, Semarang

Jawa Tengah, INDONESIA

凶lizawindalestari0902@gmail.com

\begin{abstract}
This book talking about a clever man named Zeckler came to a very backward and primitive country. This country is located far from the place of origin, initially came to this country to develop business and do business with local residents. The people there live as farmers and get food from the agricultural produce. So in that country, land is more important than money. Because soil is the key to life. But in the fact that
\end{abstract}


Zeckler is a clever cheater, he is very interested. One day this man committed fraud and traded land illegally, he also stole some local residents, the theft was carried out by violence.

KEYWORDS. Letter of the Law; Book Review;

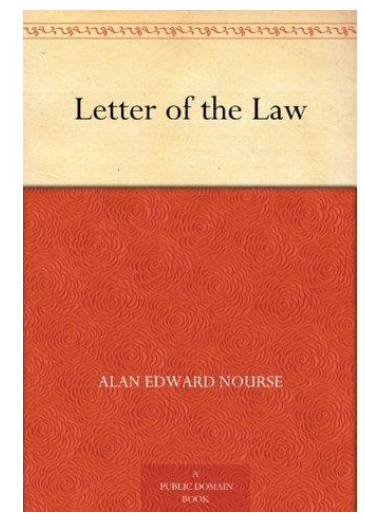

Title of Book : Letter of the Law

Author : Alan Edward Nourse

Year of Publication : 2000

Publisher : Library of Alexandria

City of Publisher : Alexandria, Egypt

Total of Pages : :123 pages

ISBN $\quad: 1492373567$

\section{GENERAL OVERVIEW OF THE BOOK}

A clever man named Zeckler came to a very backward and primitive country. This country is located far from the place of origin, initially came to this country to develop business and do business with local residents. The people there live as farmers and get food from the agricultural produce. So in that country, land is more important than money. Because soil is the key to life.

But in the fact that Zeckler is a clever cheater, he is very interested. One day this man committed fraud and traded land illegally, he also stole some local residents, the theft was carried out by violence.

Finally, he was put in an abandoned prison, the place was very dirty, dirty and there was little light. The only food he got there was water and a piece of bread. His body slowly turned thinner and emaciated, completely neglected in the dirty and smelly prison cell. There were no lawyers willing 
to accompany him or help him. He was dean in that prison for a long time. This primitive country doesn't even have a legal system. The most respected people there are the best at lying. Because liars will always find it easy to get anything. There was no court there yet and in the end to try Zeckler a trial was conducted, complete with judges, prosecutors, jury, and witnesses.

Because there were no lawyers willing to accompany Zeckler, an adviser from Zeckler's home country was brought in. The advisor was named Meyerhoff. He is a smart legal adviser. He knew about the culture that developed in the country and was quickly sensitive to what was happening. Sometimes he felt disgusted and irritated at the cunning and often deceptive Zeckler. But he also felt sorry that Zeckler was threatened with execution by the locals for his insane crimes. Especially if you see Zeckler's body getting thinner day by day

The day of the trial arrived. In the first session Zeckler was cornered, because all the accusations read by the prosecutor were "Conspiracy to overthrow the government of Altair I. Brutal murder of seventeen lawabiding citizens of the village of Karzan at the third hour before dawn in the second period after his arrival. Desecration of the Temple of our beloved Goddess Zermat, Queen of the Harvest. Conspiracy with the lesser gods to cause the unprecedented drought in the Dermatti section of our fair globe. Obscene exposure of his pouch-marks in a public square. Four separate and distinct charges of jail-break and bribery-" The judge pounded the bench for order-"Espionage with the accursed scum of Altair II in preparation for interplanetary invasion." coupled with the arrival of a witness who turned out to be a blessed goddess. This is someone who is considered sacred by the local community and is highly respected and privileged.

Finally, after listening to the words of the prosecutor and the witness, Zeckler tried to deny the witness's statement and assumed that it was all a lie, but instead he was opposed by the whole courtroom and was ridiculed and insulted by the residents present at the trial. Finally, after getting 
advice from Meyerhoff, Zeckler got a bright idea when he discussed with his legal counsel. As usual, his idea was a cunning one. He thought if everyone in that primitive country was used to lying, always lying to get what they wanted and even assuming that lying is a tradition that is preserved with a system in it, then in this country who can lie intelligently and without loopholes, then he is the winner. So Zeckler denied all the accusations and denied what the witness said, and committed his big lie in front of the judge. The judge was shocked and surprised by Meyerhoff but he could not do anything, so Zeckler was freed from the execution that had been planned by the local residents. However, Zeckler still has to undergo a series of trials that will be held in his country. And he wasn't sure if he would win it and break free again or not. This book is written with complex conflicts and many surprises in it that we could not predict before, this is one of the works of the sequel to the novel by Alan E. Nourse which was famous in his time. The story of a man who is too smart who ends up using his intelligence for bad things that are forbidden.

I think this book is very interesting because there are unexpected things in it, and it is presented with good grammar. However, there are a lot of harsh words in it, I think that harsh words can be replaced with more subtle terms. Since this book can be read by anyone, both young children and adults, it is very important to maintain a polite and good use of language. so that later it does not cause a bad effect for readers of various ages. because the words contained in the book are usually very easy to remember and imitate.

\section{LEGAL ISSUES ON THE BOOK \\ 1. False Testimony}

False testimony, namely false information given in court after taking an oath or promise, the arrangement is in the Criminal Procedure Code, namely in Ayat (1) Pasal 174 of the Criminal Procedure Code states " : apabila keterangan saksi di sidang disangka palsu, hakim ketua sidang 
memperingatkan dengan sungguh-sungguh kepadanya supaya memberikan keterangan yang sebenarnya dan mengemukakan ancaman pidana yang dapat dikenakan kepadanya apabila ia tetap memberikan keterangan palsu."

Giving false information while being a witness at a trial can be threatened with criminal sanctions as regulated in Pasal 242 KUHP ayat (1) dan (2), yang berbunyi : "Barangsiapa dalam keadaan di mana hukum kepada keterangan yang demikian, dengan sengaja memberi keterangan palsu undangundang menentukan supaya memberi keterangan di atas sumpah atau mengadakan akibat di atas sumpah, baik dengan lisan ataupun tulisan, secara pribadi maupun oleh kuasanya yang khusus ditunjuk untuk itu, diancam dengan pidana penjara paling lama tujuh tahun."

\section{Fraud}

Fraud means an act with the intent to benefit oneself or another person against the law by deception or lies. This crime is set in Pasal 378 KUHP declare that "Barang siapa dengan maksud untuk menguntungkan diri sendiri atau orang lain secara melawan hukum, dengan memakai nama palsu atau martabat palsu, dengan tipu muslihat, ataupun rangkaian kebohongan, menggerakkan orang lain untuk menyerahkan barang sesuatu kepadanya, atau supaya memberi hutang ataupun menghapuskan piutang diancam karena penipuan dengan pidana penjara paling lama empat tahun. "

In another word, Article $378 \mathrm{KUHP}$ explained that the definition of fraud is an action taken to benefit oneself or others by way of against the applicable law.

\section{Defamation}

Defamation according to Article 310 of the KUHP is to attack someone's honor or reputation by accusing someone of something, which means it is clear so that it is known to the public. Pasal 310 KUHP declare that (1) Barangsiapa sengaja merusak kehormatan atau nama baik seseorang dengan jalan menuduh dia melakukan sesuatu perbuatan dengan maksud yang 
nyata akan tersiarnya tuduhan itu, dihukum karena menista, dengan hukuman penjara selama-lamanya sembilan bulan atau denda sebanyak-banyaknya $R p$. 4.500,-“. (2) Kalau hal ini dilakukan dengan tulisan atau gambar yang disiarkan, dipertunjukan pada umum atau ditempelkan, maka yang berbuat itu dihukum karena menista dengan tulisan dengan hukuman penjara selama-lamanya satu tahun empat bulan atau denda sebanyak-banyaknya $R p .4 .500,-$.

And Pasal 315 KUHP declare that "Tiap-tiap penghinaan dengan sengaja yang tidak bersifat pencemaran atau pencemaran tertulis yang dilakukan terhadap seseorang, baik di muka umum dengan lisan atau tulisan, maupun di muka orang itu sendiri dengan lisan atau perbuatan, atau dengan surat yang dikirimkan atau diterimakan kepadanya, diancam karena penghinaan ringan dengan pidana penjara paling lama empat bulan dua minggu atau pidana denda paling banyak empat ribu lima ratus rupiah."

\section{Cheats}

Cheating means dishonest, not upright, likes to cheat is a fraud or outsmart. While deception is an act or word that is dishonest, lying, false and so on, which is more associated with words with the intent to mislead, outsmart or seek profit. In terms of the meaning of the terms fraud and cheating actually do not have a principal difference, there are only nuances of the word. However, from these two terms, it is implied that the term fraud has a broader meaning than fraud.

An important element Pasal 382 Bis of the Criminal Code concerning fraudulent acts is the element of committing fraudulent acts or acts of a deceptive nature to mislead or deceive the general public or certain people. 


\section{WHAT WE LEARN AS LAW STUDENT FROM THE BOOK? \\ 1. Appreciate differences}

Where the earth is stepped on, there the sky is upheld. Zeckler arbitrarily wronged the people of other countries and tended to always underestimate them because they were still primitive. This should not happen if we respect each other and respect other nations so that cases will not be afflicted.

\section{Always tell the truth}

Zeckler cheated too much that it plunged him into something bad. He is a successful businessman but because of too much cheating and manipulating he ends up in prison. even when he was in court he still lied. it violates the code of ethics. and also people in that primitive country lie too often so that their life is not happy and the country is difficult to progress due to lack of knowledge and education and morals are still very bad

\section{Studying \& Always exploring}

People who are highly knowledgeable and broad-minded will more easily solve problems because of their intelligent thinking. but people who think short usually will immediately take a quick alternative without thinking about the long-term impact, about what effects will arise as a result of what we do today. So that it will be a hassle at the end, because you never think about the long-term effects

\section{Keeping Polite}

Politeness is a value that cannot be abandoned to achieve harmony in social relations. By being polite to others, others will also be polite to us. Being polite is one of our obligations as humans. in the book there is rarely 
a polite behavior from local residents towards Zeckler as an immigrant and vice versa. that's why the atmosphere is getting hot and chaotic, and bullying or insults are done inappropriately. This behavior does not reflect the behavior of a good citizen and is not to be imitated.

\section{Be Fair}

Justice is something that must be enforced wherever we are, and the law will never leave justice. with the achievement of justice, prosperity will be achieved. in this book the judge is a just person who can give leniency to Zeckler and lighten his sentence even though the locals have cornered him and even though Zeckler is not one of the people in that country but the judge is still fair.

\section{Conflicting Interest Statement}

All authors declared that there is no potential conflict of interest on publishing this article.

\section{Funding}

None

\section{Publishing Ethical and Originality Statement}

All authors declared that this work is original and has never been published in any form and in any media, nor is it under consideration for publication in any journal, and all sources cited in this work refer to the basic standards of scientific citation. 